\title{
Proceedings
}

\section{Age Distribution of oak Stands within the Left-Bank Forest-Steppe, Ukraine, Broken down by Forest Categories}

\author{
Sergiy Musienko and Maksym Rumiantsev \\ Ukrainian Research Institute of Forestry and Forest Melioration named after G. M. Vysotsky, Pushkinska \\ Street 86,61024 Kharkiv, Ukraine, musienkosergij_les@ukr.net, maxrum-89@ukr.net.
}

\begin{abstract}
Oak forests perform essential environmental, protective, recreational and healthimproving functions as well as meet the needs of the national economy in valuable wood both at the local and regional levels. To determine the regime of use and provide effective forest management in the oak forests, it is advisable to improve the age structure of these stands, taking into account their functionality, which is determined by their belonging to a certain forest category. The data of the last forest inventory (as of 2011) were the basis for the calculations. In total, about 70,000 survey plots in oak stands within the Left-Bank Forest-Steppe were analysed. The area of the investigated stands was 284,094 hectares. The area of oak stands in Ukrainian Left-Bank ForestSteppe was divided according to forest categories and age groups based on forest surveying data using the inventory subcompartment database. It was found that that oak stands are mainly concentrated in recreational, health-improving and protective forests, and therefore fulfill important water conservation and soil protection functions as well as provide recreational, sanitary, hygienic, aesthetic and other environmental services. The age distribution of oak stands was revealed to be imbalanced in all forest categories, with a significant predominance of middle-aged and maturing stands. Also, a very large proportion of mature and overmature stands and a small proportion of young stands were identified. This specificity is an important reason for forestry interventions aimed at optimizing the age structure, in particular, for complex felling, including conversion felling, in middle-aged understocked stands within forests fulfilling nature protection, scientific, historic, cultural, recreational and protective functions. This will contribute to the gradual transformation of even-aged stands to uneven-aged mixed multi-storeyed ones. The composition and structure of such new stands will meet the necessary criteria for those close to natural forests.
\end{abstract}

Keywords: English oak (Quercus robur L.); forest categories; age groups; forest inventory data

\section{Introduction}

Oak forests perform essential environmental, protective, recreational and health-improving functions as well as meet the needs of the national economy in valuable wood both at the local and regional levels [1]. The functional distribution of forests is an important basis for the development of appropriate measures to ensure balanced multi-purpose use of forest ecosystems, taking into account their species and age structure [2]. To determine the regime of use and provide effective forest management in the oak forests within the Left-Bank Forest-Steppe in Ukraine, it is advisable to improve the age structure of these stands, taking into account their functionality, which is determined by their belonging to a certain forest category.

\section{Materials and Methods}

The data of the last forest inventory (as of 2011) were the basis for the calculations. In total, about 70,000 survey plots in oak stands within the Left-Bank Forest-Steppe were analysed. The area of the investigated stands was 284,094 hectares. 
The study covered oak forest resources of 29 state forestry enterprises within six administrative regions in Ukraine (Kyiv, Poltava, Sumy, Kharkiv, Cherkasy, and Chernihiv Regions).

For the oak stand analysis based on forest inventory data of the Ukrderzhlisproekt Production Association by 2011, we developed an electronic subcompartment database. The database was then converted from the .vff into .mdb format of MS Access using the NewUnPackOHOTA programme developed in the Laboratory of New Information Technologies of the Ukrainian Research Institute of Forestry and Forest Melioration [3]. The data sample required for further calculations was exported into the .xls format in Microsoft Excel 2016.

The functional categorization of forests, definition of conditions and specificities of their classification, and allocation of specially protected forest areas managed under the limited use regime were made according to the Procedure for Dividing Forests into Categories and Allocation of Specially Protected Forest Areas [4]. The oak stands were distributed by the following age groups: young, middle-aged, maturing, mature and ovemature stands [5].

\section{Results and Discussion}

The forest inventory data analysis shows that the recreational and health-improving forests make up the largest part of the total area of oak forests within Ukrainian Left-Bank Forest-Steppe, covering $38.7 \%$ (109,660 ha). The proportion of protective forests is slightly smaller, $28.1 \%$ (79,915 ha), while the part of commercial forests is $18.2 \%$ (51,790 ha). The proportion of forests within specifically protected territories and forests of scientific, historical and cultural importance is $15.0 \%$ (42,729 ha). The distribution of the total stock volume of oak forests within the forest categories is approximately the same as of area.

Oak stands in recreational and health-improving forests are forest parks $(61.9 \%$ or $67,861 \mathrm{ha})$ and commercial forests $(36.2 \%$ or 39,695 ha) in urban green belts, forests within settlements $(1.4 \%$ or $1,494 \mathrm{ha})$, and forests of the first, second and third buffer zones within sanitary protection districts of health-improving and recreational territories and zones of water-supply sources, making only $0.5 \%$ of the total area of the forests in this category (610 ha).

The largest part of the total area of protective forests $-57.5 \%$ or 45,954 ha - falls on stands that are important for environmental protection. Forest belts along rivers and around lakes and other water bodies cover $21.7 \%$ or 17,321 ha. Forests preventing soil erosion account for $18.6 \%$ or 14,881 ha; protective forest belts along railways cover $1.6 \%$ or 1,259 ha; protective forest belts along motorways of state importance occupy $0.4 \%$ or 315 ha, and state protective forest belts are $0.2 \%$ or 184 ha.

Among oak forests fulfilling nature protection, scientific, historic and cultural functions the largest area is occupied by natural monuments making $62.9 \%$ of the total area of the forests of the category, or 26,846 ha. National nature parks cover $13.8 \%$ or 5,888 ha while regional landscape parks occupy $10.2 \%$ or 4,357 ha. Protected forest districts account for $9.2 \%$ (3,938 ha), forests with especially nature protection make up $3.5 \%$ (1,512 ha), and forests of scientific or historical significance cover $0.4 \%$ only (188 ha).

The category of commercial forests includes oak forest areas not occupied by forests with nature protection, scientific, historic and cultural functions as well as recreational, health-improving and protective forests (i. e. forests with special use regime). Commercial forests are intended to meet the needs of the national economy in timber harvested in the main felling. The total area of oak stands within the commercial forests in the Left-Bank Forest-Steppe is 51,790 ha.

The analysis of forest inventory data on the age distribution of oak stands indicate imbalance with a significant predominance of middle-aged oak stands, both in area and stock, regardless of their origin.

In recreational and health-improving forests there is a significant predominance of middle-aged stands growing on an area of 89,187 ha and making $81.3 \%$ of the total area of oak forests in the category. Their stock is $23,171,100 \mathrm{~m}^{3}$ or $84.8 \%$ of the total stock volume of oak forests in the category. Maturing stands occupy an area of 9,086 ha $(8.3 \%)$, and their stock reaches $2,299,600 \mathrm{~m}^{3}(8.4 \%)$. Mature and overmature stands cover 6,827 ha $(6.2 \%)$ with a stock of $1,575,900 \mathrm{~m}^{3}(5.8 \%)$, and young stands cover 4559 ha $(4.2 \%)$ with a stock of $289,100 \mathrm{~m}^{3}(1.0 \%)$. 
Oak stands in protective forests show the following distribution by age groups: middle-aged stands are the most common and grow on an area of 64,008 ha $(80.1 \%$ of the total area of oak forests in the category). Their stock is estimated at $15,957,600 \mathrm{~m}^{3}(84.4 \%$ of the total stock volume of the oak forests in the category). Mature and overmature stands cover 6269 ha $(7.8 \%)$ while young stands, 5,113 ha $(6.4 \%)$; their stock is $1,368,400 \mathrm{~m}^{3}(7.2 \%)$ and $409,900 \mathrm{~m}^{3}(2.2 \%)$, respectively. The smallest area is occupied by maturing stands covering 4,526 ha $(5.7 \%)$, the stock of which reaches $1,164,000 \mathrm{~m}^{3}$ $(6.2 \%)$.

The analysis of the oak stands' total area distribution for the forests of nature protection, scientific, historical and cultural importance shows that the largest area $-31,192$ ha $(73.0 \%$ of the total area of oak forests in the category) - is occupied by middle-aged stands. Their total stock volume reaches $8,360,000 \mathrm{~m}^{3}$. A significant area is occupied by mature and overmature stands $(5,113 \mathrm{ha}$ or $12.0 \%$ ) and maturing stands (4,894 ha or $11.4 \%)$. Their stocks are estimated at 1,227,200 and 1,393,800 $\mathrm{m}^{3}$, respectively. Young stands grow on an area of 1,530 hectares (3.6\%) and have a stock of 117,700 $\mathrm{m}^{3}$.

In commercial forests, almost half of the oak stands' total area $(45.8 \%)$ is occupied by middleaged stands covering 23,737 ha. Their stock is $6,147,000 \mathrm{~m}^{3}$, making $46.1 \%$ of the total stock volume of oak forests in the category. Almost a third of the total area ( $31.4 \%$ or 16268 ha) is occupied by maturing stands with a stock of 5,101,600 $\mathrm{m}^{3}(38.2 \%)$. The proportions of the area of mature and overmature stands and young stands are almost the same: $11.1 \%(5,726 \mathrm{ha})$ and $11.7 \%(6,060 \mathrm{ha})$, while their stocks are $1,744,000 \mathrm{~m}^{3}(13.1 \%)$ and $349,600 \mathrm{~m}^{3}(2.6 \%)$, respectively.

\section{Conclusions}

Oak forests in the region are mainly concentrated in recreational, health-improving and protective forests: $38.7 \%$ and $28.1 \%$ of the total forest area, respectively. Therefore, they fulfill important water conservation and soil protection functions as well as provide recreational, sanitary, hygienic, aesthetic and other environmental services.

The age distribution of oak stands was revealed to be imbalanced in all forest categories, with a significant predominance of middle-aged and maturing stands. Also, a very large proportion of mature and overmature stands and a small proportion of young stands were identified.

The age distribution of oak stands is far from optimal. This specificity is an important reason for forestry interventions aimed at optimizing the age structure, in particular, for complex felling, including conversion felling, in middle-aged understocked stands within forests fulfilling nature protection, scientific, historic, cultural, recreational and protective functions. This will contribute to the gradual transformation of even-aged stands to uneven-aged mixed multi-storeyed ones. The composition and structure of such new stands will meet the necessary criteria for those close to natural forests.

Assigning each forest compartment in oak stands to a certain forest category determines the appropriate forest use regime. The results of the study should be taken into account when developing appropriate recommendations that will help maintain a complex multi-storeyed structure of oak forests, increase their productivity and strengthen their important environmental, protective, recreational and health-improving functions.

The authors declare no conflict of interest.

\section{References}

1. Tkach, V.; Rumiantsev, M.; Kobets, O.; Luk'yanets, V.; Musienko, S. Ukrainian plain oak forests and their natural regeneration. Forestry Studies 2019, 71, 17-29. https://doi.org/10.2478/fsmu-2019-0010

2. Hudyma, V. D.; Parpan, T. V.; Plikhtiak, P. P. The functional and age structure of the mountain forests of the Ukrainian Carpathians. Forestry and Forest Melioration 2018, 133, 71-77. (In Ukranian).

3. Vedmid, M. M.; Meshkova, V. L.; Zhezhkun, A. M. Algorithm for reveal of low valuable young stands in the oakeries by forest inventory data. Forestry and Forest Melioration 2006, 110, 54-58. (In Ukranian). 
4. Procedure for Dividing Forests into Categories and Allocation of Specially Protected Forest Areas 2007. Resolution of Cabinet of Ministers of Ukraine. No 733 dated 27.07.2007. (In Ukranian). Available online: https://zakon.rada.gov.ua/laws/show/733-2007-\%D0\%BF. (accessed on 28 August 2020).

5. Hrom, M. M. Forest inventory; RVV NLTU: Lviv, Ukraine, 2007; 416 pp. (In Ukranian).

Publisher's Note: MDPI stays neutral with regard to jurisdictional claims in published maps and institutional affiliations.

(c) 2020 by the authors. Submitted for possible open access publication under the terms and conditions of the Creative Commons Attribution (CC BY) license (http://creativecommons.org/licenses/by/4.0/). 